\title{
Hemoplasma infection in wild captive carnivores ${ }^{1}$
}

\author{
Filipe T. Carneiro ${ }^{2}$, Marcela C. Scalon², Gabrielle Amorim², Wanessa A.C. Silva², \\ Sandy M. Honorato ${ }^{2}$, Fernanda M.A.M. Pereira ${ }^{3}$, Luisa H.R. Silva ${ }^{3}$, \\ Larissa C. Aquino ${ }^{2}$ and Giane R. Paludo ${ }^{2 *}$ (D)
}

\begin{abstract}
Carneiro F.T, Scalon M.C., Amorim G., Silva W.A.C, Honorato S.M., Pereira F.M.A.M, Silva L.H.R., Aquino L.C. \& Paludo G.R. 2020. Hemoplasma infection in wild captive carnivores. Pesquisa Veterinária Brasileira 40(4):293-299. Laboratório de Patologia Clínica Veterinária, Faculdade de Agronomia e Medicina Veterinária, Universidade de Brasília, Av. L4 Norte, Brasília, DF 70910-900, Brazil. E-mail: giane@unb.br

Hemoplasmas are bacteria able to adhere themselves loosely to the plasma membrane of erythrocytes and may parasitize several species of mammals. There are three known species of hemoplasmas that parasitize domestic and wild cats: Mycoplasma haemofelis, 'Candidatus Mycoplasma haemominutum' and 'Candidatus Mycoplasma turicensis'. Dogs are infected by at least two species of hemoplasmas: 'Candidatus Mycoplasma haematoparvum' and Mycoplasma haemocanis. The hemoplasmoses are very important in veterinary clinics, either because of its worldwide distribution and severity of clinical signs, depending on parasite species and host immune competence, or due to its zoonotic potential and capability of infecting endangered species. This study set out to investigate which hemoplasmas species parasitize different captive wild carnivores in order to clarify the epidemiology of hemoplasmoses in wild animals. Furthermore, the research intended to characterize the hematological changes caused by different species of hemotropic mycoplasmas infection in order to establish their clinical importance to wild species and the capacity of these species to become a reservoir of studied agents. Samples of 33 wild felids and 18 wild canids were investigated using polymerase chain reaction (PCR) to detect hemoplasmas DNA and it was observed that the occurrence of infection in these species is $45.5 \%$ and $83.3 \%$, respectively. Factors such as age, gender or anaemia are not more frequent in animals positive for the infection. Therefore, it is concluded that infection caused by hemoplasmas in wild carnivores has high prevalence, and either agent pathogenicity is low, or chronic stage is more frequent, resulting in a low rate of diagnosis.
\end{abstract}

INDEX TERMS: Hemoplasma, infection, wild captive, carnivores, hemotropic mycoplasmas, hemoparasites, anaemia, diagnose, polymerase chain reaction, wildlife animals.

\begin{abstract}
RESUMO.- [Infecção por hemoplasmas em carnívoros selvagens cativos.] Hemoplasmas são bactérias capazes de aderir frouxamente à membrana plasmática de eritrócitos e que podem parasitar diversas espécies de mamíferos. São conhecidas três espécies de hemoplasmas que parasitam felídeos domésticos e selvagens: Mycoplasma haemofelis, 'Candidatus Mycoplasma haemominutum' and 'Candidatus Mycoplasma
\end{abstract}

\footnotetext{
${ }^{1}$ Received on September 13, 2019.

Accepted for publication on October 16, 2019.

${ }^{2}$ Laboratório de Patologia Clínica Veterinária, Faculdade de Agronomia e Medicina Veterinária, Universidade de Brasília (UnB), Av. L4 Norte, Brasília, DF 70910-900, Brazil. *Corresponding author: giane@unb.br

${ }^{3}$ Fundação Jardim Zoológico de Brasília, Avenida das Nações, Via L4 Sul s/n, Brasília, DF 70610-100, Brazil.
}

turicensis'. Cães são infectados por ao menos duas espécies de hemoplasmas: Candidatus Mycoplasma haematoparvum' and Mycoplasma haemocanis. As hemoplasmoses são de grande importância na clínica veterinária, tanto pela sua distribuição ubíqua e severidade dos sinais clínicos, a depender da espécie do parasita e imunocompetência do hospedeiro, quanto pelo seu potencial zoonótico e capacidade de infectar espécies ameaçadas. Este estudo visa investigar quais espécies de hemoplasmas parasitam diferentes carnívoros selvagens de cativeiro, a fim de esclarecer a epidemiologia das hemoplasmoses em animais selvagens. Além disso, o trabalho objetivou caracterizar as alterações hematológicas causadas pela infecção por diferentes espécies de micoplasmas hemotrópicos visando estabelecer sua importância clínica para espécies selvagens e a capacidade destas espécies de 
se tornar reservatórios dos agentes estudados. Amostras de 33 felídeos selvagens e de 18 canídeos selvagens foram investigadas por meio da reação em cadeia da polimerase (RCP) para detectar o DNA dos agentes e foi observado que a ocorrência da infecção por hemoplasmas nestas espécies é de $45,5 \%$ e $83,3 \%$, respectivamente. Fatores como idade, sexo ou anemia não são mais frequentes em animais positivos para a infecção. Dessa forma, conclui-se que a infecção causada por hemoplasmas em carnívoros selvagens possui alta prevalência, no entanto ou a patogenicidade dos agentes é baixa ou o estágio crônico da infecção é mais frequente, resultando em uma baixa frequência diagnóstica.

TERMOS DE INDEXAÇÃO: Infecção, hemoplasma, carnívoros, selvagens cativos, micoplasmas hemotrópicos, hemoparasitas, anemia, diagnóstico, reação da polimerase em cadeia, animais selvagens.

\section{INTRODUCTION}

Hemoplasmas, or hemotropic mycoplasmas are important causative agents of infectious anaemia. which have been found in all continents, except Antarctica, leading to the belief that its distribution is linked to urbanization. However, the epidemiology and transmission of these agents remains somewhat obscure (Tasker et al. 2003, Biondo et al. 2009).

There are three known species of hemoplasmas that parasitize domestic and wild cats: Mycoplasma haemofelis, 'Candidatus Mycoplasma haemominutum' and 'Candidatus Mycoplasma turicensis'. It is known that Mycoplasma haemofelis induces anemia in immunocompetent hosts, whereas 'Candidatus Mycoplasma haemominutum' and 'Candidatus Mycoplasma turicensis' appear to be less pathogenic (Almosny 1998, André et al. 2010, Allison \& Little 2013).

Dogs may be infected by at least two species of mycoplasma: Mycoplasma haemocanis and 'Candidatus Mycoplasma haematoparvum' (O'Dwyer et al. 1997, Biondo et al. 2009). In addition, a canine hemoplasma more similar to 'Candidatus Mycoplasma haemominutum' than to 'Candidatus Mycoplasma haematoparvum' was detected by polymerase chain reaction (PCR) in a dog in Londrina, Brazil, and another hemoplasma with 98-100\% homology to 'Candidatus Mycoplasma turicensis found in cats also amplified in 7 out of 10 splenectomized dogs in Porto Alegre, Brazil (André et al. 2012). It is unclear if these are new canine hemoplasmas or if dogs are susceptible to infection by feline hemoplasmas.

Parasitism by hemoplasmas has been reported in different wild species, such as: Leopardus geoffroyi, Leopardus wiedii, Leopardus pardalis, Puma concolor, Panthera onca, Lynx lynx, Felis silvestris silvestris, Puma yagouaroundi, Canis lupus and Speothos venaticus, including vulnerable species like Panthera leo, and Leopardus tigrinus, or endangered like Panthera tigris, and Lynx pardinus (Birkenheuer et al. 2003, Bayliss et al. 2009, André et al. 2010, Almeida et al. 2011, Santos et al. 2013).

Furthermore, Anaplasma platys, Bartonella henselae and 'Candidatus Mycoplasma haematoparvum' coinfection of a veterinarian who moved amongst Grenada, Ireland and South Africa has been described in literature. The woman reported contact with several domestic and wild animals, as well as fleas, ticks, lice, biting flies, mosquitoes, spiders and mites. She developed symptoms such as fainting, headaches, photophobia, muscle twitching, tonic-clonic seizures, ataxia and memory loss (Maggi et al. 2013). Also, a 34-year-old HIV- positive patient has tested positive for hemoplasmas in Brazil (Dos Santos et al. 2008). These cases alert to the zoonotic potential of hemoplasmosis and severity of its clinical signs in humans, especially combined with other infectious agents or in immunocompromised patients.

In dogs and cats, infection of red blood cells by hemoparasites can result in intravascular or extravascular anaemia. Other clinical signs may include depression, splenomegaly, fever, anorexia, dehydration, wasting, lethargy, icterus, and sudden death. Anaemia is regenerative, unless there is a primary disease to inhibit erythropoiesis. For cats, hemoplasmosis commonly is secondary to feline leukemia virus (FeLV) or feline immunodeficiency virus (FIV) (Willi et al. 2007, Thrall 2012).

Hemoparasite identification traditionally occurs by viewing blood smear under light microscope. Nevertheless, this diagnostic method is rather limited since it greatly depends on the amount of parasite circulating, as well as technician experience to distinguish the parasite from other structures such as Howell-Jolly boddies, basophilic stippling or even artifacts caused by poor staining. Therefore, the development of a PCR technique highly sensitive and specific assures an effective diagnosis, even in situations where there is a small amount of the microorganism (Thrall 2012).

Even though hemoplasmas can infect different species of wild carnivores and cause clinical signs extreme enough to compromise the conservation of endangered species, there is little information on the occurrence of hemoplasma infection in these species. Moreover, considering the zoonotic potential of the disease, it is necessary to assess whether there is a likelihood of wild animals to act as reservoirs and transmit it to humans and domestic animals.

The objectives of this study were to determine the occurrence and identify the species of hemoplasmas that affect captive wild canids and felids by conventional PCR. Additionally, our aim was to verify haematological changes caused by hemoplasmas and study the epidemiology of hemoplasma infection in carnivores, correlating the occurrence of the disease in different wild species.

\section{MATERIALS AND METHODS}

Blood samples of 33 wild felids and 18 wild canids from both Brasília Zoo and a conservationist breeding facility were used. The zoo provided samples from three jaguars (Panthera onca), one ocelot (Leopardus pardalis), two pampas cats (Leopardus pajerus), three pumas (Puma concolor), one margay (Leopardus wiedii), one oncilla (Leopardus tigrinus), four tigers (Panthera tigris), three jaguarundis (Puma yagouaroundi), two lions (Panthera leo), six maned wolves (Chrysocyon brachyurus), five hoary foxes (Lycalopex vetulus), five crab-eating foxes (Cerdocyon thous) and two bush dogs (Speothos venaticus). The breeding facility provided samples of eight jaguars, one ocelot, a pampas cat and three pumas.

Samples were collected under authorization of the Ethics Committee on Animal Use (CEUA-UnB, Doc. no. 130988/2015) and the "Instituto Brasileiro do Meio Ambiente e dos Recursos Naturais Renováveis" (IBAMA, SISBIO no. 46097).

Samples from two natural infected domestic dogs and four domestic cats from the Veterinary Hospital of "Universidade de Brasília" (UnB) were used as positive controls for the PCR techniques. These animals had been previously diagnosed with hemoplasmas through real-time PCR (qPCR) and their samples had been sequenced 
and stored in a biobank at the Laboratory of Veterinary Molecular Microbiology and Clinical Pathology at the UnB.

In order to reduce stress caused by physical and chemical restraint, all wildlife samples were collected during routine veterinary procedures of the host institution.

Samples of venous blood were taken by puncturing either the cephalic vein or jugular ventral caudal. These samples were collected in an atraumatic manner and quickly packed into tubes containing ethylenediaminetetraacetic acid (EDTA).

Samples from the breeding facility were sent to the Veterinary Clinical Pathology Laboratory at the University of Brasilia, where an automated haematologic counter for veterinary use (Horiba ABX Micros ESV 60) was used to determine red blood cell (RBC) and white blood cell (WBC) count. Samples from the zoo were sent to the zoo's Veterinary Hospital Laboratory Nucleus, where it was held manual RBC and WBC count with a Neubauer chamber.

The difference in methodology for WBC and RBC counts for samples from different origins took place in order to ensure that processing was carried out as quickly as possible. However, the same technician processed and analyzed all samples from both institutions in order to reduce variation to a minimum. Further processing was identical for samples from both origins. The packed cell volume (PCV) was determined by microhematocrit technique and whole blood smears were prepared and stained with a Romanowsky type stain (Diff-Quick) in order to perform leukocyte differential count, platelets count, morphological observation of blood cells and hemoparasites search.

After performing complete blood counts, samples were frozen and sent to the Laboratory of Veterinary Molecular Microbiology and Clinical Pathology at the University of Brasilia, where the DNA was extracted using commercial kits (Illustra blood genomicPrep Mini Spin Kit ${ }^{\circledR}$, GE Healthcare of Brazil Ltda, São Paulo/SP), following the manufacturer's recommendations. The DNA samples were kept at $-20^{\circ} \mathrm{C}$ until the PCR.

In order to confirm DNA extraction and attest the quality and integrity of extracted material, and absence of inhibitors, a PCR was carried out to detect the gene encoding glyceraldehyde 3-phosphate dehydrogenase using the primers GAPDH- F and GAPDH-R (Birkenheuer et al. 2003).

Specific primers for the 16S rRNA gene were used to identify hemoplasmas. For the standardization of PCR techniques, domestic dogs and cats with a positive laboratory diagnosis using qPCR and sequencing were used. The conditions of PCR techniques were determined experimentally. Samples from domestic animals known to be positive were used as positive controls, while miliQ water was used as a negative control in all experiments.

Six different standard PCR techniques were carried out for the detection of positive samples of hemoplasmas: for hemoplasmas genus using primers HBT-F and HBT-R, for Mycoplasma haemofelis with HF-F1 and HF-R3 primers and for 'Candidatus Mycoplasma haemominutum' 1183-F and 1290R primers (Criado-Fornelio et al. 2003). Primers CMtFw2 and CMtRev2 was used for 'Candidatus Mycoplasma turicensis' detection (Aquino et al. 2014). For Mycoplasma haemocanis, HCAN-F and HCAN-R primers was used and, for 'Candidatus Mycoplasma haematoparvum', HPARV-F and HPARV -R (Torkan et al. 2014). Rickettsiae was also identified through PCR by using one technique to identify Anaplasmataceae family, capable of identifying Ehrlichia canis, E. chaffeensis, E. muris, Anaplasma equi, A. phagocytophila, A. platys, $A$. marginale, A. centrale, Wolbachia pipientis, E. sennetsu, Neorickettsia risticii and $N$. helminthoeca with EHR16sd and EHR16sr primers, and another for Anaplasma platys using PLATYS as foward primer (Inokuma et al. 2000). Also, other PCR specific for identification of
E. canis, using ECAN5 and He3 primers was performed (Murphy et al. 1998). The final volume of each PCR mix was $25 \mu$ l, containing $1 X$ PCR buffer, primers, MgCl2, dNTPs, Taq DNA polymerase (Invitrogen ${ }^{\circledR}$ Brasil Ltda, São Paulo, Brazil) and DNA sample.

The results of the PCRs were analysed in agarose electrophoresis gel stained with ethidium bromide and observed under fluorescence transilluminator.

Data was entered into Microsoft Office Excel ${ }^{\circledR}$ and statistical analysis was performed with SPSS software (SPSS Inc., Chicago/IL, USA). Categorical variables (gender, origin, species, age, presence of anaemia and PCR result) were evaluated using chi-square test, following a 95\% confidence interval. Kolmogorov-Smirnov and Shapiro-Wilk tests were used to test the normality of continuous variables (PCV, number of erythrocytes and leukocytes). MannWhitney U test was used to analyze the data did not follow normal distribution. Results were considered significant when $\mathrm{P}<0.05$.

\section{RESULTS}

Initially we compared complete blood cell count (CBC) results of animals from different origins, in order to investigate if the difference in processing methodology resulted in some kind of bias. No differences were found, suggesting that this disagreement was not a determining factor in the results.

Considering the 33 wild felids tested, fifteen cats (45.5\%) were positive for hemoplasmas, being two jaguars, two ocelots, three pampas cats, four pumas, one margay, two jaguarundis and a lion (Table 1). There was no statistical difference between the positive and negative animals when compared to origin, institution, gender, age (greater or less than 2 years old) or anaemia (Table 2-4). There was also no difference between

Table 1. Results of the PCR for hemoplasma by felid species

\begin{tabular}{lccc}
\hline & $\begin{array}{c}\text { Number (\%) of } \\
\text { positives }\end{array}$ & $\begin{array}{c}\text { Number (\%) of } \\
\text { negatives }\end{array}$ & Total \\
\hline Leopardus wiedii & $1(3)$ & $1(3)$ & $2(6)$ \\
Panthera onca & $2(6.1)$ & $9(27.3)$ & $11(33.4)$ \\
Leopardus pardalis & $2(6.1)$ & $0(0)$ & $2(6.1)$ \\
Leopardus pajerus & $3(9.1)$ & $0(0)$ & $3(9.1)$ \\
Puma concolor & $4(12.1)$ & $2(6.1)$ & $6(18.2)$ \\
Panthera tigris & $0(0)$ & $4(12.1)$ & $4(12.1)$ \\
Puma yagouaroundi & $2(6.1)$ & $1(3)$ & $3(9.1)$ \\
Panthera leo & $1(3)$ & $1(3)$ & $2(6)$ \\
TOTAL & $15(45.5)$ & $18(54.5)$ & $33(100)$
\end{tabular}

Table 2. Number (\%) of positive and negative animals for hemoplasma infection compared to gender by Pearson's ChiSquare

\begin{tabular}{|c|c|c|c|c|}
\hline \multirow{3}{*}{$\begin{array}{c}\text { Hemoplasma } \\
\text { PCR }\end{array}$} & \multicolumn{4}{|c|}{ Gender } \\
\hline & \multicolumn{2}{|c|}{ Felids } & \multicolumn{2}{|c|}{ Canids } \\
\hline & Male & Female & Male & Female \\
\hline Negative & $7(21.2)^{a}$ & $11(33.3)^{\mathrm{a}}$ & $1(5.6)^{a}$ & $2(11.1)^{a}$ \\
\hline Positive & $10(30.3)^{\mathrm{a}}$ & $5(15.2)^{\mathrm{a}}$ & $9(50)^{\mathrm{a}}$ & $6(33.3)^{a}$ \\
\hline Total & 17 (51.5) & $16(48.5)$ & $10(55.6)$ & $8(44.4)$ \\
\hline
\end{tabular}

Felids: $p=0.112$, Canids: $p=0.396$; ${ }^{a}$ Equal letters in different columns indicate proportions are not significantly different. 
Table 3. Number (\%) of positive and negative animals for hemoplasma infection compared to age by Pearson's ChiSquare

\begin{tabular}{lcccc}
\hline \multirow{2}{*}{$\begin{array}{c}\text { Hemoplasma } \\
\text { PCR }\end{array}$} & \multicolumn{2}{c}{ Felids } & \multicolumn{2}{c}{ Canids } \\
\cline { 2 - 5 } & $\begin{array}{c}<\text { years } \\
\text { old }\end{array}$ & $\begin{array}{c}>2 \text { years } \\
\text { old }\end{array}$ & $\begin{array}{c}<2 \text { years } \\
\text { old }\end{array}$ & $\begin{array}{c}>2 \text { years } \\
\text { old }\end{array}$ \\
\cline { 2 - 5 } & $2(6.1)^{\mathrm{a}}$ & $16(48.5)^{\mathrm{a}}$ & $1(5.6)^{\mathrm{a}}$ & $2(11.1)^{\mathrm{a}}$ \\
Negative & $1(3)^{\mathrm{a}}$ & $14(42.4)^{\mathrm{a}}$ & $5(27.8)^{\mathrm{a}}$ & $10(55.5)^{\mathrm{a}}$ \\
Positive & $3(9.1)$ & $30(90.9)$ & $6(33.4)$ & $12(66.6)$
\end{tabular}

Felids: $p=0.658$; Canids: $p=1.000$; ${ }^{\text {a }}$ Equal letters in different columns indicate proportions are not significantly different.

Table 4. Number (\%) of positive and negative animals for hemoplasma infection compared to presence or not of anaemia by Pearson's Chi-Square

\begin{tabular}{lcccc}
\hline \multirow{2}{*}{$\begin{array}{c}\text { Hemoplasma } \\
\text { PCR }\end{array}$} & \multicolumn{3}{c}{ Felids } & \multicolumn{2}{c}{ Canids } \\
\cline { 2 - 5 } & PCV $\geq 27$ & PCV $<27$ & PCV $\geq 38$ & $P C V<38$ \\
\hline Negativo & $12(50)^{\mathrm{a}}$ & $1(4.2)^{\mathrm{a}}$ & $2(12.5)^{\mathrm{a}}$ & $1(6.3)^{\mathrm{a}}$ \\
Positivo & $10(41.7)^{\mathrm{a}}$ & $1(4.2)^{\mathrm{a}}$ & $4(25)^{\mathrm{a}}$ & $9(56.2)^{\mathrm{a}}$ \\
Total & $22(91.7)$ & $2(8.4)$ & $6(37.5)$ & $10(62.5)$
\end{tabular}

Felids: $p=0.902$, Canids: $p=0.247 ; \mathrm{PCV}=$ packed cell volume; ${ }^{a}$ Equal letters in different columns indicate proportions are not significantly different.

PCV, RBC, WBC and platelet count of positive and negative animals. No hemoplasmas were found in blood smears from both positive and negative animals.

Two jaguars were positive for 'Candidatus Mycoplasma haemominutum' and 'Candidatus Mycoplasma haematoparvum', a pampas cat for Mycoplasma haemocanis and an ocelot and a pampas cat for ' $\mathrm{Ca}$. M. haematoparvum'. The other ten felids positive for hemoplasmas had no species detected by PCR techniques used in this study (Table 5).

Among the positive felines, a jaguar and an ocelot were positive for Anaplasma platys, a puma was positive for Ehrlichia canis and one jaguar, one ocelot, two pampas cats, one puma and one oncilla were also tested positive for some other Anaplasmataceae family agent. Since the animals were naturally infected, it is difficult to say which agent caused the infection first. However, it is quite likely that one of the agents has compromised the hosts immune system and favoured the infection of other.

Fifteen canids (83.3\%) were positive for hemoplasmas out of the 18 tested, being six maned wolves, four hoary foxes, four crab-eating foxes and one bush dog (Table 6). There was no difference between positive and negative animals when compared regarding gender, age or the presence of anaemia (Tables 2-4). Likewise, there was no difference in comparison between PCV, RBC, WBC and platelet count from positive and negative animals.

Two crab-eating foxes were tested positive for 'Candidatus Mycoplasma haemominutum', one hoary fox, and two crabeating foxes were positive for Mycoplasma haemocanis and one bush-dog had the presence of 'Candidatus Mycoplasma haematoparvum' in its sample. Even so, nine positives did not
Table 5. Number (\%) of positive and negative samples for the different PCR techniques

\begin{tabular}{lcccc}
\hline & \multicolumn{2}{c}{ Felids } & \multicolumn{2}{c}{ Canids } \\
\hline & $\begin{array}{c}\text { PCR } \\
\text { positive }\end{array}$ & $\begin{array}{c}\text { PCR } \\
\text { negative }\end{array}$ & $\begin{array}{c}\text { PCR } \\
\text { positive }\end{array}$ & $\begin{array}{c}\text { PCR } \\
\text { negative }\end{array}$ \\
\hline Hemoplasma genus & 15 & 18 & 15 & $3(16.7)$ \\
& $(45.5)$ & $(54.5)$ & $(83.3)$ & \\
Mycoplasma haemofelis & $0(0)$ & $33(100)$ & $0(0)$ & $18(100)$ \\
$\begin{array}{l}\text { Candidatus Mycoplasma } \\
\text { haemominutum }\end{array}$ & $2(6.1)$ & 31 & $2(11.1)$ & 16 \\
$\begin{array}{l}\text { Ca. Mycoplasma } \\
\text { turicensis }\end{array}$ & $0(0)$ & $33(100)$ & $0(0)$ & $18(100)$ \\
Mycoplasma haemocanis & $1(3)$ & $32(97)$ & $3(16.7)$ & 15 \\
& & & & $(83.3)$ \\
$\begin{array}{l}\text { Ca. Mycoplasma } \\
\text { haematoparvum }\end{array}$ & $4(12.1)$ & 29 & $1(5.6)$ & 17 \\
& & $(87.9)$ & & $(94.4)$
\end{tabular}

Table 6. Results of the PCR for hemoplasma by canid species

\begin{tabular}{lccc}
\hline & $\begin{array}{c}\text { Number (\%) } \\
\text { of positives }\end{array}$ & $\begin{array}{c}\text { Number (\%) of } \\
\text { negatives }\end{array}$ & Total \\
\hline $\begin{array}{l}\text { Chrysocyon } \\
\text { brachyrurus }\end{array}$ & $6(33.3)$ & $0(0)$ & $6(33)$ \\
Lycalopex vetulus & $4(22.2)$ & $1(5.6)$ & $5(27.8)$ \\
Cerdocyon thous & $4(22.2)$ & $1(5.6)$ & $5(27.8)$ \\
Speothos venaticus & $1(5.6)$ & $1(5.6)$ & $6(11.2)$ \\
Total & $15(83.3)$ & $3(16.7)$ & $33(100)$
\end{tabular}

have the species of hemoplasma detected by PCR techniques used here (Table 5).

No co-infection between hemoplasmas species was encountered in any of the studied samples from canids. Nevertheless, among positive hemoplasma samples one maned wolf and a hoary fox were positive for $A$. platys and $E$. canis; a crab-eating fox, a hoary fox and three maned wolves were positive for A. platys; a hoary fox and a maned wolf tested positive for E. canis; and a crab-eating fox, two hoary foxes and a maned wolf were positive for some unspecified Anaplasmataceae family agent. In the blood smear belonging the maned wolf positive for E. canis morula was found in platelets, but hemoplasmas were not found in smears of any of the studied canids.

\section{DISCUSSION}

Other studies have been conducted investigating hemoplasma infection in wild felines in recent years and the agent occurrence differs considerably. In a study with 54 felines in captivity Illinois and Florida, in the United States, there were only two $(0.04 \%)$ positive tigers (André et al. 2010$)$. This value is much below the $45.5 \%$ found in this study, although it also samples from captive animals.

Brasília Zoo is located in a major metropolitan center and, therefore, faces a relevant problem with domestic and synanthropic animals such as stray cats and capybaras (Hydrochoerus hydrochaeris). Cats and capybaras have free access in and out the institution and may be responsible for 
vector traffic, therefore, maintaining high infection rates in wild specimens. Study regarding these animals and their vectors is essential in order to gather information about their role in this cycle.

In another study, conducted with 165 felines from zoos in São Paulo, Mato Grosso and the Distrito Federal, the occurrence of hemoplasma infection was $13.9 \%$ in felids, totalling 23 infected animals. Of all the animals, ten belonged to Brasilia Zoo and three (30\%) of which tested positive for 'Candidatus Mycoplasma haemominutum' (Birkenheuer et al. 2003). Though the total occurrence is much lower, when considering only the animals located in the Distrito Federal, despite only ten animals having been sampled, there is greater proximity to the occurrence found in this study. This suggests that both hemoplasma infections in wild felines can be more frequent in the Federal District than in Mato Grosso and São Paulo, and that it has grown over the years, going from $30 \%$ to $45.5 \%$. This problem may be once again related to stray animals, increasingly frequent in the vicinity of Brasilia Zoo.

A third study evaluated blood samples and serosanguinous fluids of 257 free-living or captive wild felids of 15 different species, originating from Africa, South America and Europe, achieved 96 positive animals (37\%) for hemoplasma infection. The felids were divided into five groups with different frequencies of infection: Serengeti lions (98\%), Eurasian lynxes (44\%), European wild cats (39\%), Iberian lynxes (37\%) and Brazilians wild felids (10\%) (Willi et al. 2007). Although the total occurrence is very close to that found in this paper, there is considerable disparity when comparing only Brazilian wild felids. The authors imply that the difference in the frequency of infection among the five groups may be due to differences in habitat, either from one captivity to another, or from captivity to free-living. It should be considered, therefore, that the samples of Brazilian wild felids were taken from the Zoological Park of São Paulo, located in Brazilian Atlantic Forest, while samples of the current paper were collected from animals that live in Brazilian Cerrado. The differences between these two ecosystems can influence factors such as temperature variation, facilitating or hindering that animals suffer heat stress, as well as altering susceptibility to ectoparasites that potentially convey the agent in question. This may account for the variation of $35.5 \%$ in the frequency of infection between papers.

The infection of domestic cats is potentially pathogenic as evaluated previously (Dumler et al. 2001, Ebani \& Bertelloni $2014)$, but this has not often been reported in wild felids (Birkenheuer et al. 2003, Almeida et al. 2011). One can reach the hypothesis that animals are in the chronic stage of infection, less pathogenic strains of the agent caused the infection, or the hosts had better immune competence and thus did not have anemia (Foley et al. 1999, Filoni et al. 2006, Fortes et al. 2011). One of the pumas positive to ' $\mathrm{Ca}$. M. haemominutum' and 'Candidatus Mycoplasma haematoparvum' had its sample tested twice in one year apart and were positive in both tests. This finding confirms the theory of this animal being in the chronic phase of infection and increases the likelihood that the same is happening with the other test subjects.

Researches with domestic cats indicate that males are more prone to hemoplasma infection than females, and Mycoplasma haemofelis is more common in young animals, whereas 'Ca. M. haemominutum' is most reported in older animals (Fournier et al. 2007, Fortes et al. 2011). However, just like in this paper, Willi et al. (2007) found no correlation between gender and hemoplasma infection in other research investigating wild felids. Co-infection by different species of hemoplasmas is often reported in domestic cats.

Co-infection by different species of hemoplasmas is often reported in domestic cats (Filoni et al. 2006, Fortes etal. 2011, Adaszek et al. 2013). The percentage of animals concurrently infected with more than one specie of hemoplasma was $21.4 \%$ in a research that only investigated the presence of M. haemofelis, 'Ca. M. haemominutum' and 'Ca. M. turicensis' in wild felids (Almeida et al. 2011). Interestingly only two pumas had simultaneous infections with more than one species of hemoplasma, in both cases ' $\mathrm{Ca}$. M. haemominutum' and ' $\mathrm{Ca}$. M. haematoparvum'. It is worth noting that there is a very close proximity between these two species and the two PCR techniques may be identifying the same agent (Fortes et al. 2011).

Hemoplasma infection in domestic dogs has been described in the literature, particularly associated with splenectomized or immunosuppressed animals. A study of 889 dogs in Switzerland found an occurrence of infection by Mycoplasma haemocanis or ' $\mathrm{Ca}$. M. haematoparvum' of $1.2 \%$, being the former $0.9 \%$ and latter $0.3 \%$ (Hegarty et al. 2015). Another study surveyed the same agents in 154 dogs from Ribeirão Preto and found a canine hemoplasma occurrence of $2.5 \%$, $1.9 \%$ of infections by $M$. haemocanis and $0.6 \%$ by ' $C a$. $M$. haematoparvum' (Inokuma et al. 2000). The occurrence found in the present study significantly outweighs that which was found in the other papers, either because of the difference of host species evaluated or because of the variation in the availability of vectors in the environment.

Another study investigated the occurrence of hemoplasmas in 100 wild canids, three European wolves (Canis lupus) and 97 Brazilian wild canids kept in captivity in zoos from São Paulo, Mato Grosso and the Distrito Federal. The frequency of hemoplasma infection was estimated at 4\%, a mark well below the $83.3 \%$ found in this study. Nevertheless, two wolves (2\%) tested positive for 'Ca. M. haemominutum', and two bush dogs (2\%) were infected with ' $\mathrm{Ca}$. M. haematoparvum'. In the present paper two crab-eating foxes (11.1\%) were also positive for ' $\mathrm{Ca}$. M. haemominutum' and a bush dog was positive for 'Ca. M. haematoparvum' (Birkenheuer et al. 2003).

It should be noted that all assessed canids came from the same institution and that the high rate of infection may be the result of not only regional ecological conditions, but also local health conditions. Again, the difficulty to perform efficient vector control of wandering and synanthropic animals may have been decisive in this case and will need more targeted studies.

Interestingly, all the maned wolves were positive for hemoplasmas and rickettsiae. The animals live in enclosures side by side and communicate through railings, which is certainly a factor that facilitates the transmission of pathogens. Yet, the species of hemoplasma infecting them was not detected, but three individuals were positive for $A$. platys, one for $E$. canis, and one for A. platys and E. canis, showing a triple infection. This animal, a female cub, presented anaemia and died in about two months. Another maned wolf, born in the same litter, but only positive for hemoplasma and A. platys, presented thrombocytopenia e anaemia. Four months later 
the animal was diagnosed with an osteometabolic disease and was euthanized. Among the studied animals there was also a hoary fox with a triple infection. Unlike the maned wolf, it showed only thrombocytopenia without any signs on physical examination. This study converges with another investigating hemoplasma infection in dogs, both domestic and wild, by showing that hemoplasmas have low pathogenicity in these species, showing no correlation between anaemia, or any other hematologic finding, and infection (Inokuma et al. 2000, Birkenheuer et al. 2003, Hegarty et al. 2015). It is noteworthy that even animals co-infected with Rickettsia showed no statistically significant haematological abnormalities compared to uninfected animals.

Studies with domestic dogs also point out that there is no correlation between hemoplasma infection and gender or age group (Hegarty et al. 2015), but no other study with wild canids tried this comparison.

The most frequent hemoplasma species found in felids was 'Ca. M. haematoparvum', while the most frequent in canids was $M$. haemocanis, with an incidence of $12.1 \%$ and $16.7 \%$, respectively. On the other hand, the less frequent species were $M$. haemofelis and 'Ca. M. turicensis', which were found in none of the specimens analysed.

\section{CONCLUSIONS}

Hemoplasma infections are frequent in captive wild carnivores, however, significant haematological findings have not been found, leading us to believe that the hemoplasmosis does not usually appear as a disease in these animals, possibly because they are chronically infected or parasitized by less pathogenic species or strains of the agent. Furthermore, the high incidence of hemoplasmas in wild animals from major population centers implies that they can act as reservoirs and perpetuate the infection of domestic animals.

This seems to be the first study to report Mycoplasma haemocanis and 'Candidatus Mycoplasma haematoparvum infecting wild felids, and M. haemocanis infecting wild canids. Nevertheless, we must emphasize the similarity between the genomes $M$. haemocanis and $M$. haemofelis, especially in the $16 \mathrm{~S}$ rRNA gene, and that sequencing of the positive samples must be carried out in order to distinguish between species.

The use of other molecular techniques, such as gene sequencing, is essential to elucidate if infected individuals without species identification regard to small changes in the genome of the parasite or if there are new species infecting wild carnivores.

Future researches on the infection of synanthropic animals that have contact with both wild captive animals and domestic animals, as well as on their vectors, are also crucial to understanding the disease better.

Acknowledgements.- The authors thank "Coordenação de Aperfeiçoamento de Pessoal de Nível Superior" (CAPES) and "Conselho Nacional de Pesquisa" (CNPq) for providing scholarships that made this research possible. We also would like to thank Brasília Zoo and NEx for allowing their crew to collaborate with science.

\section{REFERENCES}

Adaszek L., Górna M., Skrzypczak M., Buczek K., Balicki I. \& Winiarczyk S. 2013. Three clinical cases of Anaplasma phagocytophilum infection in cats in Poland. J. Feline Med. Surg. 15(4):333-337. <http://dx.doi. org/10.1177/1098612X12466552><PMid:23143840>

Allison R.W. \& Little S.E. 2013. Diagnosis of rickettsial diseases in dogs and cats. Vet. Clin. Pathol. 42(2):127-144. <http://dx.doi.org/10.1111/ vcp.12040><PMid:23647393>

Almeida A.P., Cunha L.M., Bello A.C., Cunha A.P., Domingues L.N., Leite R.C., Labruna M.B. 2011. A novel Rickettsia infecting Amblyomma dubitatum ticks in Brazil. Ticks Tick-borne Dis. 2(4):209-212. <http://dx.doi.org/10.1016/j. ttbdis.2011.08.003><PMid:22108014>

Almosny N.R.P. 1998. Ehrlichia canis (Donatien \& Lestoquard, 1935): avaliação parasitológica, hematológica e bioquímica sérica da fase aguda de cães e gatos experimentalmente infectados. Doctoral Dissertation in Veterinary Parasitology, Graduate Program in Veterinary Medicine, Universidade Federal Rural do Rio de Janeiro, RJ. 115p.

André M.R., Dumler J.S., Scorpio D.G., Teixeira R.H.F., Allegretti S.M. \& Machado R.Z. 2012. Molecular detection of tick-borne bacterial agents in Brazilian and exotic captive carnivores. Ticks Tick-borne Dis. 3(4):247-253. <http:// dx.doi.org/10.1016/j.ttbdis.2012.04.002><PMid:22749737>

André, M.R., Adania C.H., Machado R.Z., Allegretti S.M., Felippe P.A.N., Silva K.F. \& Nakaghi A.C.H. 2010. Molecular and serologic detection of Ehrlichia spp. in endangered Brazilian wild captive felids. J. Wildl. Dis. 46(3):1017-1023. <http://dx.doi.org/10.7589/0090-3558-46.3.1017> <PMid:20688716>

Aquino L.C., Hicks C.A., Scalon M.C., Lima M.G.M., Lemos M.S., Paludo G.R., Helps C.R. \& Tasker S. 2014. Prevalence and phylogenetic analysis of haemoplasmas from cats infected with multiple species. J. Microbiol. Methods 107:189-196. <http://dx.doi.org/10.1016/j.mimet.2014.10.013> <PMid:25447887>

Bayliss D.B., Morris A.K., Horta M.C., Labruna M.B., Radecki S.V., Hawley J.R., Brewer M.M. \& Lappin M.R. 2009. Prevalence of Rickettsia species antibodies and Rickettsia species DNA in the blood of cats with and without fever. J. Feline Med. Surg. 11(4):266-270. <http://dx.doi.org/10.1016/j. jfms.2008.06.007><PMid:18786845>

Biondo A.W., Santos A.P.D., Guimarães A.M.S., Vieira R.F.D.C., Vidotto O., Macieira D.B., Almosny N.R.P., Molento M.B., Trimenetsky J., Morais H.A., González D. \& Messick J.B. 2009. A review of the occurrence of hemoplasmas (hemotrophic mycoplasmas) in Brazil. Revta Bras. Parasitol. Vet. 18(3):1-7. <http://dx.doi.org/10.4322/rbpv.01803001>

Birkenheuer A.J., Levy M.G. \& Breitschwerdt E.B. 2003. Development and evaluation of a seminested PCR for detection and differentiation of Babesia gibsoni (Asian genotype) and B. canis DNA in canine blood samples. J. Clin. Microbiol. 41(9):4172-4177.<http://dx.doi.org/10.1128/jcm.41.9.41724177.2003><PMid:12958243>

Criado-Fornelio A., Martinez-Marcos A., Buling-Sarana A. \& Barba-Carretero J.C. 2003. Presence of Mycoplasma haemofelis, Mycoplasma haemominutum and piroplasmids in cats from southern Europe: a molecular study. Vet. Microbiol. 93(4):307-317. <http://dx.doi.org/10.1016/s0378-1135(03)00044-0> $<$ PMid:12713893>

Dos Santos A.P., Santos R.P., Biondo A.W., Dora J.M., Goldani L.Z., Oliveira S.T., Guimarães A.M.S., Timenetsky J., Morais H.A., González F.H.D. \& Messick J.B. 2008. Hemoplasma infection in HIV-positive patient, Brazil. Emerg. Infect. Dis. 14(12):1922. <http://dx.doi.org/10.3201/eid1412.080964> <PMid:19046522>

Dumler J.S., Barbet A.F., Bekker C.P., Dasch G.A., Palmer G.H., Ray S.C., Rikihisa Y. \& Rurangirwa F.R. 2001. Reorganization of genera in the families Rickettsiaceae and Anaplasmataceae in the order Rickettsiales: unification of some species of Ehrlichia with Anaplasma, Cowdria with Ehrlichia and Ehrlichia with Neorickettsia, descriptions of six new species combinations and designation of Ehrlichia equi and'HGE agent'as subjective synonyms of Ehrlichia phagocytophila. Int. J. Systematic Evol. Microbiol. 51(Pt 6):2145-2165. <http://dx.doi.org/10.1099/00207713-51-6-2145> $<$ PMid:11760958> 
Ebani V.V. \& Bertelloni F. 2014. Serological evidence of exposure to Ehrlichia canis and Anaplasma phagocytophilum in Central Italian healthy domestic cats. Ticks Tick-borne Dis. 5(6):668-671. <http://dx.doi.org/10.1016/j. ttbdis.2014.04.019><PMid:25113987>

Filoni C., Catão-Dias J.L., Bay G., Durigon E.L., Jorge R.S.P., Lutz H. \& HofmannLehmann R. 2006. First evidence of feline herpesvirus, calicivirus, parvovirus, and Ehrlichia exposure in Brazilian free-ranging felids. J. Wildl. Dis. 42(2):470-477. <http://dx.doi.org/10.7589/0090-3558-42.2.470> $<$ PMid:16870878>

Foley J.E., Foley P., Jecker M., Swift P.K. \& Madigan J.E. 1999. Granulocytic ehrlichiosis and tick infestation in mountain lions in California. J. Wildl. Dis. 35(4):703-709. <http://dx.doi.org/10.7589/0090-3558-35.4.703> <PMid:10574529>

Fortes F.S., Santos L.C., Cubas Z.S., Barros-Filho I.R., Biondo A.W., Silveira I., Labruna M.B. \& Molento M.B. 2011. Anti-Rickettsia spp. antibodies in free-ranging and captive capybaras from southern Brazil. Pesq. Vet. Bras. 31(11):1014-1018. <http://dx.doi.org/10.1590/S0100-736X2011001100013>

Fournier P.E., Raoult D. \& Parola P. 2007. Bacteriology, taxonomy, and phylogeny of Rickettsia. Infect. Dis. Ther. Ser. 43:1. <http://dx.doi. org/10.3109/9781420019971.001>

Hegarty B.C., Qurollo B.A., Thomas B., Park K., Chandrashekar R., Beall M.J., Thatcher B. \& Breitschwerdt E.B. 2015. Serological and molecular analysis of feline vector-borne anaplasmosis and ehrlichiosis using species-specific peptides and PCR. Parasites Vectors 8(1):320. <http://dx.doi.org/10.1186/ s13071-015-0929-8> <PMid:26062723>

Inokuma H., Raoult D. \& Brouqui P. 2000. Detection of Ehrlichia platys DNA in brown dog ticks (Rhipicephalus sanguineus) in Okinawa Island, Japan. J. Clin. Microbiol. 38(11):4219-4221. <http://dx.doi.org/10.1128/ JCM.38.11.4219-4221.2000><PMid:11060094>

Maggi R.G., Mascarelli P., Havenga L., Naidoo V. \& Breitschwerdt E. 2013. Co-infection with Anaplasma platys, Bartonella henselae and 'Candidatus
Mycoplasma haematoparvum in a veterinarian. Parasites Vectors 6(1):103. <http://dx.doi.org/10.1186/1756-3305-6-103><PMid:23587235>

Murphy G.L., Ewing S.A., Whitworth L.C., Fox J.C. \& Kocan A.A. 1998. A molecular and serologic survey of Ehrlichia canis, E. chaffeensis, and E. ewingii in dogs and ticks from Oklahoma. Vet. Parasitol. 79(4):325-339. <http://dx.doi.org/10.1016/s0304-4017(98)00179-4><PMid:9831955>

O’Dwyer L.H., Guimarães L. \& Massard C.L. 1997. Ocorrência de infecção múltipla por Babesia canis, Hepatozoon canis e Haemobartonella canis, em um cão esplenectomizado. Revta Bras. Ciênc. Vet. 4(2):83-84. <http:// dx.doi.org/10.4322/rbcv.2015.077>

Santos L.G.F., Melo A.L.T., Jaune F.W., Ziliani T.F., Girardi A.F. \& Aguiar D.M. 2013. Hematological values associated to the serological and molecular diagnostic in cats suspected of Ehrlichia canis infection. Revta Bras. Parasitol. Vet. 22(4):470-474. <http://dx.doi.org/10.1590/S1984-29612013000400005> $<$ PMid:24473870>

Tasker S., Helps C.R., Day M.J., Harbour D.A., Shaw S.E., Harrus S. \& Belford C.R. 2003. Phylogenetic analysis of hemoplasma species: an international study. J. Clin. Microbiol. 41(8):3877-3880. <http://dx.doi.org/10.1128/ JCM.41.8.3877-3880.2003><PMid:12904408>

Thrall M.A. 2012. Regenerative anemia, p.94-97. In: Thrall M.A., Weiser G., Allison R. \& Campbell T. (Eds), Veterinary Hematology and Clinical Chemistry. 2nd ed. John Wiley and Sons, Ames.

Torkan S., Aldavood S.J., Sekhavatmandi A. \& Moshkelani S. 2014. Detection of haemotropic Mycoplasma (Haemobartonella) using multiplex PCR and its relationship with epidemiological factors in dogs. Comp. Clin. Pathol. 23(3):669-672. <http://dx.doi.org/10.1007/s00580-012-1668-2>

Willi B., Filoni C., Catão-Dias J.L., Cattori V., Meli M.L., Vargas A., Martínez F., Roelke M.E., Ryser-Degiorgis M.P. \& Leutenegger C.M. 2007. Worldwide occurrence of feline hemoplasma infections in wild felid species. J. Clin, Microbiol. 45(4):1159-1166. <http://dx.doi.org/10.1128/JCM.02005-06> <PMid:17301277> 